\title{
DIREITO E FILOSOFIA POLÍTICA EM PLATÃO E ARISTÓTELES
}

\section{LAW AND POLITICAL PHILOSOPHY TO PLATO AND ARISTOTLE}

\author{
${ }^{1}$ Flávio Pansieri \\ ${ }^{2}$ Rene Sampar
}

\section{Resumo}

O presente artigo tem por intuito analisar alguns temas políticos recorrentes aos pensadores da Grécia clássica, tendo como enfoque a filosofia política de Platão e Aristóteles, cujas paradigmáticas discussões ainda são legítimas no contexto estatal contemporâneo. Através da revisão bibliográfica destes autores e de alguns de seus intérpretes, o texto desenvolve os temas da liberdade, justiça e formas de governo, fortalecendo a atualidade destas filosofias no cotidiano jurídico e político dos Estados.

Palavras-Chave: liberdade; justiça; formas de governo; Platão; Aristóteles.

\begin{abstract}
This article is meant to examine some recurrent political issues to the philosophers classical Greece, with special focus in political think of Plato and Aristotle, whose paradigmatic discussions are still legitimate even in the contemporary context. Through literature review of these authors and some of his best readers, the text develops the themes of freedom, justice and forms of government, strengthening the actuality of these philosophies in the daily legal and political States.
\end{abstract}

Keywords: freedom; justice; forms of government; Plato; Aristotle.

\footnotetext{
${ }^{1}$ Doutor em Direito pela UFSC. Mestre em Direito pela USP. Conselheiro Federal da OAB. Presidente do Conselho Fundador da Academia Brasileira de Direito Constitucional. Professor da PUCPR. Advogado. E-mail: pansieri@pansierikozikoski.com.

${ }^{2}$ Mestre em Filosofia Política pela UEL. Especialista em Direito Constitucional pelo IDCC. Especialista em Filosofia Política pela UEL. Bacharel em Direito pela UEL. Professor e Advogado. E-mail: renesampar@msn.com
} 


\section{INTRODUÇÃO}

O presente artigo tem por escopo analisar alguns temas políticos trabalhados por Platão e Aristóteles, pensadores da Grécia clássica que estabeleceram verdadeiros paradigmas no estudo da política. Sua forma de pensar se tornou preponderante durante a Idade Média, e ainda serve de matriz para diversas discussões. Através de uma metodologia que congrega a revisão bibliográfica de suas obras e de alguns de seus comentadores, o objetivo deste texto é trazer à tona a relevância do trabalho destes dois titãs do pensamento do mundo antigo.

Sem olvidar da extensão de suas análises e dos diferentes eixos temáticos que as compõem, escolheu-se abordar temas no que toca à filosofia política, em especial a teoria da justiça, a ideia de liberdade e as formas de governo para os dois pensadores. Destaca-se que, dentre as formas de governo, são conhecidas as suas críticas à democracia, crítica esta que precisa ser analisada no bojo e no contexto de suas escolas de pensamento e de seu período histórico, sob pena de se cometer anacronismos.

Deste modo, o presente artigo se divide de modo estratégico em duas partes. A primeira trabalha o pensamento platônico. O foco está em demonstrar como Platão pretendia construir a sua ideia de justiça a partir do arquétipo da cidade idílica, denominada Callipolis. Para tanto, sua forma de governo ideal é a aristocracia, tendo como governante o filósofo, isto é, aquele que mais tempo dedicou à educação. A segunda parte do artigo desenvolve parte do pensamento aristotélico, com enfoque especial em suas noções de governo e na dinâmica da sociedade que ele considerava hábil à conquista da liberdade.

\section{0 pensamento político de Platão}

As bases filosóficas do pensamento de Platão guardam interessante proximidade com a sua história de vida. As nuances de seu pensamento estão concatenadas com o momento histórico vivido pela Grécia, qual seja, a decadência democrática na polis, além da morte de seu mestre, Sócrates. Hannah Arendt (1993, p. 91), corroborada por autores como Werner Jaeger e François Châtelet, lembra que a condenação de Sócrates pelos cidadãos de Atenas produziu grande efeito em Platão. O fato de seu mestre não ter convencido os juízes de sua inocência e afastar as condenações a ele imputadas levaram o discípulo a duvidar da validade 
do método socrático (maiêutica) e da própria política. Com isto, Platão invalida o governo democrático para lhe substituir pela aristocracia do pensamento, de sorte que a esfera pública seria um arquétipo cujo grande artífice era o Rei-filósofo.

Mostra-se oportuno enunciar estes fatos com maior acuidade. Neste sentido, Platão nasce em uma família aristocrática e vive no transcorrer da Guerra do Peloponeso - cujo desfecho marca o declínio de Atenas, posteriormente invadida pelo Império Macedônico. Estes fatores produzem no pensador uma consequência interessante: pelo fato de ter nascido no momento de declínio da polis (somado à condenação de Sócrates pela Assembleia) e por ter origem nobre, Platão não vê na democracia uma forma de governo que promova a justiça, mas sim a aristocracia ${ }^{3}$. Em sua principal obra política, $A$ República, o autor estabelece a arquitetura fundamental de sua Callipolis aristocrática, a organização civil idílica que proporcionaria o desenvolvimento social e pessoal em busca de justiça e liberdade.

A construção da cidade perfeita em Platão passa pelo estabelecimento de um paradigma a ser atingido, um arquétipo que serviria como um instrumental comparativo entre aquilo que é o ideal e a realidade ateniense. Isto porque sua filosofia transita entre o sensível e o inteligível por uma herança da filosofia pitagórica. Assim como os sofistas, Platão parte do mundo de imprecisão do empirismo, mas avança para a gnose conceitual, intelectual, em busca daquilo que não é efêmero, de conceitos absolutos. Neste afã transcendental, o filósofo cria a famosa teoria das ideias, a sobreposição do mundo inteligível sobre o sensível material.

A alegoria da Caverna $^{4}$ indica que a forma de governo ideal para Platão é a aristocracia fundada no conhecimento das coisas. O comando desta polis ficaria, naturalmente, a cargo do filósofo, aquele que é o amante do saber e único capaz de realizar a justiça de modo satisfatório ${ }^{5}$. A filosofia política platônica tem como pressuposto básico o

\footnotetext{
${ }^{3}$ Ernst-Wolfgang Böckenförde (2012, p. 97) traça o quadro de Atenas no período de Platão: progressiva perda de hegemonia de Atenas para Esparta por conta da Guerra do Peloponeso, ausência de unidade política interna, intensas disputas partidárias em favor de lobbies e ainda o enfraquecimento da democracia.

${ }^{4} \mathrm{O}$ maior emblema da teoria das ideias de Platão está no Mito ou Alegoria da Caverna. A busca da essência imutável das coisas se dá pela razão, que é adquirida progressivamente. No mito citado, que está presente no livro VII de A República (2012, p. 315-320), Platão representa o mundo sensível como imagens em uma parede. Somente pela razão, se conhece a verdade que está fora da caverna. Os que evadem a caverna são os filósofos, os homens de razão, aqueles aptos a governar a polis.

${ }^{5}$ No diálogo entre Sócrates (Platão) e Glauco (Livro V de A República), Sócrates diz ser capaz de reformar as estruturas dos Estados com uma simples mudança: transmitir o comando do governo para os filósofos. Neste sentido: "enquanto não forem, ou os filósofos reis nas cidades, ou os que agora se chamam reis e soberanos filósofos genuínos e capazes, e se dê esta coalescência do poder político com a filosofia, enquanto as numerosas naturezas que atualmente seguem um destes caminhos com exclusão do outro não forem impedidas forçosamente de o fazer, não haverá trégua dos males, meu caro Gláucon, para as cidades, nem sequer, julgo eu,
} 
desenvolvimento de seu ideal de justiça. Para tanto, Platão estabelece um caminho lógico estruturante do sistema político a ser trilhado para se constituir bons cidadãos e uma cidade justa que possibilite, dentre outros fatores, a liberdade (em oposição à escravidão).

\subsection{A teoria de justiça platônica}

No livro primeiro de A República, Sócrates (Platão) questiona o conceito de justiça a três indivíduos. Céfalo dirá que a justiça é dizer a verdade e restituir aquilo que se tomou de alguém. Sendo comerciante, tem especial ligação com esta noção de troca e pagamento. Já para Polemarco, a justiça é dar a cada um o que se deve. Polemarco também é um comerciante, que deriva sua concepção de justiça a partir de sua atividade profissional. Por último Trasímaco, um sofista que quer se mostrar mais perspicaz que os demais perante Sócrates, diz que a justiça é uma coação mistificada, isto é, não explícita, exercida pelos governantes a favor de seus interesses privados. Em outras palavras, o ideal de justiça é norteado segundo o interesse do mais forte, uma imposição dos mais poderosos sobre a coletividade.

As três concepções apresentadas por Céfalo, Polemarco e Trasímaco têm uma característica comum: todas relacionavam a justiça a partir de seu mundo privado, com caracteres que lhes eram peculiares. Imiscuído a este discurso, opõe-se o ideal platônico de busca pelo mundo das ideias eternas. Com isso, antecipa-se que nenhum dos três estaria apto para o governo da cidade, pois Céfalo, Polemarco e Trasímaco não se mostravam capazes de transcender à sua realidade terrena e se colocar em busca do bem comum. Na narrativa, Sócrates, por óbvio, discorda de todas estas compreensões de justiça, sobretudo, por se tratarem de disposições individuais frente a um determinado evento e, em especial, por alocarem o ideal de justiça em uma tábula teleológica.

Para demonstrar sua oposição, Sócrates ${ }^{6}$ conclui que não há problema então em aparentar ser justo mesmo sendo injusto. Assim, conta-lhes o mito do anel de Giges ${ }^{7}$, no qual

para o gênero humano, nem antes disso será jamais possível e verá a luz do sol a cidade que há pouco descrevemos" (PLATÃO, 2012, p. 251).

${ }^{6}$ Sócrates não deixou escritos. Seu discípulo, Platão, utilizava-o em meio a diálogos para transmitir suas ideias.

Por isto se utiliza o nome de Sócrates neste ponto do artigo que trata de Platão.

${ }^{7}$ Este mito é contado por Platão no Livro II de A República. Giges é um pastor de ovelhas que encontra um anel que o torna invisível. Tendo este poder literalmente nas mãos, Giges deixa de ser um homem honesto e se torna um criminoso, a ponto de matar o rei. O questionamento fundamental por detrás da lenda é uma provocação de Sócrates aos seus opositores: é mais vantajoso ser justo ou aparentar ser justo? 
o pastor, quando envolto pelas sombras do anonimato, altera completamente sua natureza e sua noção de justiça (PLATÃO, 2012, p. 54-57). O que Platão está questionando é: a justiça é uma virtude e como tal deve ser buscada por si ou, por outro lado, os indivíduos são justos apenas por receio de penalidades? Platão quer com isso mostrar a falibilidade das opiniões que não seriam capazes de produzir um conceito abstrato aplicável à coletividade.

Entretanto, neste contexto, onde estaria a justiça? Na política. A teoria platônica de justiça se bifurca em dois contextos: ela estará presente tanto no ordenamento da cidade como no próprio indivíduo. Seu ponto de partida não são as relações sociais, mas a justiça pessoal. Em outras palavras, a convicção do justo suscita primeiro no indivíduo, a partir do equilíbrio integrativo e harmônico de três forças, para depois dizer respeito ao campo social em que ele se insere. Estas três forças anímicas presentes em cada ser humano são: a razão (sabedoria e autoridade), a coragem (bravura e vigilância) e o desejo sensível (moderação e preocupação com as necessidades elementares da matéria). Tais forças se conectam à divisão social estabelecida por Platão para a sua cidade ideal ${ }^{8}$. Tal divisão se ancora em três classes, quais sejam: a dos comerciantes e agricultores, a dos guerreiros e a dos magistrados (filósofos governantes).

Acerca desta estrutura de justiça platônica, Tércio Sampaio (2002, p. 80) lembra que a liberdade grega não está associada a escolhas, mas a querer algo possível; desejar algo impossível é não ser livre, pois o querer pressupõe o poder. Há clara e inafastável convergência entre a liberdade e a necessidade. Assim, na escola de pensamento grega - ao menos no tempo de Platão - não havia espaço para se querer algo impossível, como uma mulher participar das discussões políticas na ágora, pois ela não era livre pela sua vida estar adstrita à casa. Para tanto, existia a necessidade de se estar liberado do trabalho. Não bastava a uma mulher querer, pois sua condição era um impeditivo.

É notável na obra de Platão a ideia de que temas muito caros à política nascem a partir do indivíduo, de sua interioridade. Liberdade e justiça se deflagram na interioridade de cada um e se refletem no social, conceitos apropriados pelos filósofos políticos na modernidade em suas conotações essencialmente públicas e jurídicas como direitos constitucionais dos cidadãos. Nas palavras de Durant (2000, p. 46), em Platão, o comportamento pessoal se reflete diretamente na esfera pública, na medida em que o Estado "é o que é porque as pessoas

\footnotetext{
${ }^{8}$ Como ficará mais claro adiante, a ideia de justiça em Platão é cada pessoa viver dentro do seu estamento social determinado pelo tempo de estudos de cada um.
} 
são o que são". Deste modo, "não devemos esperar ter melhores Estados enquanto não tivermos homens melhores". Somente um cidadão livre de vícios e em harmonia consigo mesmo poderia construir uma polis igualmente livre, numa espécie de quid pro quo.

Este é o foco do pensador ao instituir todo um complexo sistema estrutural da polis erigido sobre a educação igualitária. Seguindo os passos de Sócrates, a instrução gradativa e contínua dos indivíduos é a mola propulsora que possibilitaria a fuga das paixões descontroladas e os vícios de toda ordem (escravidão psicológica e física), fatores que guardam relação direta com a esfera pública e sua forma de governo. A hipótese platônica é a de que a partir do momento em que cada cidadão fosse instruído e exercesse a sua aptidão ou ofício, estar-se-ia estabelecido o seu governo idílico, isto é, uma república (politeia) aristocrática fundada no mérito por conhecimento e sabedoria ${ }^{9}$. Em outras palavras, a liberdade política viceja quando os cidadãos exercem um ofício direcionado à sua classe pela sua própria aptidão, não interferindo no locus destinado aos demais.

\subsection{A fundação da Callipolis e o seu sistema educacional}

Desta forma, o surgimento da polis está relacionado aos indivíduos. O fundamento para a constituição da polis em Platão (assim como para Aristóteles) é a satisfação das necessidades, das carências pessoais. Ernst-Wolfgang Böckenförde (2012, p. 113) lembra que a ideia de satisfação de necessidades não se trata apenas de carências materiais e prementes, ligadas às funções biológicas, como a busca por alimento ou segurança pessoal. Estas são questões essenciais, mas não são únicas. Trata-se de um rol que abarca o desenvolvimento ético, moral, intelectual e cultural. Para ilustrar tais assertivas, Platão desenvolve um diálogo entre Sócrates e Glauco na qual estabelece três formas distintas de cidade baseadas na especialização e posterior divisão do trabalho: cidade mínima, cidade de luxo e cidade ideal.

A cidade mínima existe para a satisfação das necessidades básicas de sua população. É composta, deste modo, apenas de camponeses, artesãos e comerciantes; a justiça nesta cidade está na troca comercial entre estas funções. Todavia, superadas as dificuldades com a própria sobrevivência, o desejo impulsionado pelas trocas comerciais leva as pessoas a desejarem o luxo e o supérfluo. Isto conduz ao desenvolvimento da cidade de luxo.

\footnotetext{
${ }^{9}$ Will Durant nomeia como aristocracia democrática (2000, p. 55) a forma criada por Platão para ressaltar que nela não reside o caráter hereditário. Contudo, democracia é um conceito chave de conotação negativa na filosofia platônica de modo que não será utilizada esta expressão cunhada por Durant.
} 
A segunda cidade é a de luxo ou opulenta, que existe para atender aos desejos opulentos dos cidadãos. Para tanto, é necessária maior extensão territorial obtida através de conquista de novas terras e submissão de outros povos. Além disso, uma cidade com vasto poderio econômico precisa estar imune a ataques externos. Surge a figura do soldado, necessária para a segurança da cidade, em primeiro lugar porque a cidade opulenta está inchada dos mais variados desejos, inflando também o ego das pessoas ${ }^{10}$, e também porque os indivíduos não são bondosos. O soldado, portanto, é peça fundamental para o arranjo deste agrupamento, tornando-se guardiões do regime político da cidade, da conduta de seus membros e ainda de guarnecer o povo contra ataques externos. Sua essencial função justifica um investimento na educação para a preparação virtuosa desta classe, fundamentada em aulas de música para a alma e ginástica para o corpo. Neste ponto, Platão já começa a sinalizar para a necessidade de um grupo de sábios com autoridade para comandar esta cidade, indicando o filósofo como o mais adequado para este posto.

Por fim, a cidade ideal é descrita por Platão a partir da divisão dos cidadãos em três classes. A classe dos comerciantes deve possuir bens. Sua virtude é a temperança, parcimônia adquirida pelo mundo dos negócios. A segunda classe é a dos soldados. Eles não teriam posses. Dada a importância estratégica de sua função, a polis como um todo contribuiria para lhes fornecer o necessário à sua subsistência. Além de não possuir bens, o soldado platônico não deveria ter família, de modo a reservar sua atenção única e exclusivamente às questões públicas. Caso tivesse filhos, estes seriam criados pela polis para se tornarem futuros soldados. A virtude dos guerreiros é a coragem e a prudência. A terceira e última classe é a dos magistrados, aqueles que não tiveram o tempo sorvido pela busca por bens, como os comerciantes, nem pelo anseio de se tornarem heróis, como os guerreiros, mas que se dedicaram aos estudos. Sua função é governar e promover a justiça, tanto pela qualidade das leis criadas como pelo controle exercido sobre as outras classes de modo a manter as pessoas aptas às funções exercidas. A virtude cívica dos magistrados é a sabedoria.

O ingresso em cada uma destas classes se daria pela educação. Com efeito, o processo pedagógico tem início antes mesmo do nascimento. Como Platão concebe um modelo social eugênico que não se baseia na divisão em famílias, os que possuíssem saúde debilitada não poderiam ter filhos. Conforme admoesta Will Durant (2000, p. 55-56), o sistema idealizado

\footnotetext{
${ }^{10}$ Neste comentário, acredita-se que Platão está fazendo menção a sua cidadã natal, Atenas. Segundo a tradição, a inveja era o seu pecado capital.
} 
por Platão constitui uma espécie de eleição educacional para determinado cargo, no qual não haveria resquícios ou divisões a partir de castas, influências ou tradição, nem tampouco falta de oportunidade aos que dispõe de parcos recursos financeiros. Todos receberiam o mesmo tratamento, não sendo importante a origem e o passado deste recém chegado. Nesta medida, para lapidar os futuros cidadãos da Callipolis, não se pode admitir que o sistema educacional os prepare desenvolvendo apenas o seu potencial físico, como ocorria com os guerreiros de Esparta, visando-se também a delicadeza possibilitada pela harmonia necessária à construção musical bem como a visão estratégica obtida por meio de jogos.

Todas as crianças, de ambos os sexos e de todas as classes, receberiam a instrução nestes saberes até os dez anos de idade. O sistema é dividido em períodos de preparação. Os que não se destacavam retornariam ao seio familiar para aprenderem o ofício dos pais, relacionados a atividades econômicas e agrícolas. Os demais assumiriam outro período de formação e seriam inseridos nas artes marciais, sendo educados até os vinte anos. Completados vinte anos, far-se-ia nova avaliação. Os que se destacavam passariam a aprender também a administração da cidade; os reprovados ficariam como guardiões auxiliares. A próxima seleção ocorreria após trinta anos; os reprovados ficariam em cargos subalternos da administração pública e os aprovados estudariam estratégia militar e principalmente dialética. Nova avaliação após trinta e cinco anos de idade; os que não lograssem êxito adquiririam cargos superiores na administração e os aprovados passariam para a última fase de formação, destinada ao estudo da ética, da física e da política. Após cinquenta anos de estudo, os melhores se tornariam magistrados (filósofos) para governar a polis ${ }^{11}$.

Platão não olvida em lembrar que os que não possuírem formação adequada "jamais serão capazes de governar satisfatoriamente a cidade" (PLATÃO, 2012, p. 322). E admoesta ainda que qualquer intercâmbio entre as classes seria “o maior dos prejuízos para a cidade e

\footnotetext{
${ }^{11}$ Os filósofos, no período de Platão, eram qualificados como inábeis para o mundo político por serem homens de conhecimento em busca de resposta para as grandes questões da humanidade. Por outro lado, segundo Leo Strauss (2013, p. 53-54), também os filósofos de modo geral não se sentiam motivados a pensar a política democrática e, portanto, eivada de opiniões -, uma vez que sua busca transcendia o senso comum. Resolver problemas mundanos seria se manter preso na escuridão da caverna. Com interesses opostos, filosofia e política se opunham em profunda distância. Platão resolve esta questão ao alocar o seu filósofo no comando da polis. Assevera Werner Jaeger que "a vida predominantemente contemplativa que o filósofo se vê obrigado a levar dentro do mundo presente que o cerca não aparece na República como seu destino último". Sob qual perspectiva o filósofo transcenderá do seu estado contemplativo ao mundo "real" da política? Explica Jaeger que "na República ideal, o filósofo deixará o estado de mera contemplação para abraçar um estado de criação. Converterse-á em "demiurgo" e trocará a única tarefa criadora que nas circunstâncias atuais the é dado realizar, a sua própria formação pela formação de caracteres humanos, tanto no campo da vida privada como no do serviço público. Converter-se-á assim no grande pintor que estruturará a imagem da polis autêntica à luz do modelo divino que traz dentro de si" (JAEGER, 1995, p. 861).
} 
com razão se poderia classificar como o de maior dos danos" (PLATÃO, 2012, p. 188). Desta forma, conforme já ressaltado, a justiça platônica em sua vertente política compreende o equilíbrio entre as classes de modo a cada um exercitar a sua função para que atingisse a excelência. Isto é, o justo para este filósofo não seria todos os homens tentarem ser magistrados, por exemplo, mas cada qual, em sua classe, buscar se aprimorar até o mais alto nível de sofisticação possível. Estando a alma dos homens em equilíbrio, a cidade estaria organizada e os indivíduos seriam livres em seu interior e em sua classe (não seriam escravos de si nem de outros).

Assim, o conceito de justiça "situa-se acima de todas as normas humanas e remonta até a sua origem na própria alma. É na mais íntima natureza desta que deve ter o seu fundamento aquilo que o filósofo denomina justo" (JAEGER, 1995, p. 756). Este é o esteio para que se atinja o bem e se construa uma sociedade livre e justa. Por sua vez, o mal é uma tríade desarmônica, ou seja, desarmonia do homem consigo mesmo, desarmonia entre os homens e desarmonia entre o homem e a natureza. A corrupção, por sua vez, seria combatida pelo senso de dever.

Resta claro, portanto, que em Platão, justiça e liberdade se constituem na cidade idílica: os indivíduos teriam formação para não se tornarem escravos de si e de suas paixões bem como atuariam dentro de um círculo de iguais em formação e talentos, o que proporcionaria a liberdade em sua plenitude.

E por que a democracia não é a forma de governo apropriada para a manutenção da liberdade? Para tanto, é necessário analisar as cinco formas de governo apontadas por Sócrates (Platão) no capítulo VIII da República - nesta ordem: aristocracia, timocracia, oligarquia, democracia e tirania - dispostas numa escala descendente em relação à forma perfeita para o governo da polis ideal. Ao passo da exposição, o autor esboça as causas que levam os governos ascendentes a se liquefazerem nos vícios dos descendentes, isto é, quais comportamentos e situações levam a aristocracia a se transformar em timocracia, esta em oligarquia, democracia até a tirania, a pior das formas por proporcionar o menor lastro de liberdade. Dito de outro modo, não há decantação de uma forma com a outra, ao contrário, as deficiências de uma forma de governo só tornam mais agudo o defeito da outra forma de governo, numa tensão que mais se distancia da cidade ideal, a Callipolis, modelo de justiça e liberdade. 


\subsection{As formas de governo e a afirmação da liberdade}

A forma de Estado da cidade idílica de Platão é peculiar, uma vez que, embora seja disposta de modo hierárquico quanto ao governo, ao menos se configura como república dentro das classes, na qual todos detêm igualdade de participação. É certo que não se configura como uma monarquia uma vez que não há direitos sucessório-hereditários para a transmissão de poder, mas um critério temporal-educacional. Quanto a forma de governo, não há dúvidas de que a aristocracia é o modelo mais adequado para se atingir os propósitos almejados por seu entusiasta. Mas não se trata de qualquer aristocracia, e sim aquela fundada sob o arrimo do conhecimento, da filosofia, do tempo dedicado à reflexão.

Assim, o governo timocrático é aquele fundado em ambição e honra, comandado por guerreiros e soldados. Esta forma de governo é imperfeita para Platão por lhe faltar dois elementos fundamentais na formação dos guerreiros: a filosofia e a música, a única mistura “defensora da virtude” (PLATÃO, 2012, p. 370). Com efeito, faltará a sabedoria necessária para as decisões, uma vez que a gnose destinada aos guerreiros é mais baseada na ginástica. Os filhos dos guerreiros no comando da polis, seus naturais sucessores, não terão a formação adequada e gerarão descendentes que, paulatinamente, afastar-se-ão das artes mais elevadas. O resultado é que não se verificará a divisão da sociedade proposta por Platão, misturando os indivíduos entre as classes. Além disso, soldados são "nascidos mais para a guerra do que para a paz", tornando-se cobiçosos por novas conquistas (PLATÃO, 2012, p. 368). A sociedade então fundada sob o pacto da honra e da espada se degenera na busca por riqueza e domínio, transformando-se em uma oligarquia.

A oligarquia se funda na divisão entre ricos e pobres. Alicerçada sobre a riqueza, a honra outrora buscada pela timocracia se perde, restando apenas a avareza. Segundo Platão, os inimigos dos avaros não são conquistadores de outras partes do mundo, mas os pobres que circundam os muros de seus domínios. Para sua defesa, os mais ricos constituem guardas e pequenos exércitos. Diante deste quadro, o filósofo vislumbra a existência de dois Estados, o dos ricos e o dos pobres, que conspirarão constantemente um contra o outro. Verifica-se aqui a corrosão da cidadania, o pior dos males que se origina a partir da oligarquia e se segue nas outras formas degeneradas (democracia e tirania). Tal corrosão se dá quando o lucro se coloca acima da política e possibilita ao estrangeiro fazer parte do Estado sem nenhum lastro político, apenas para comprar e vender propriedades aos mais abastados. É a fórmula da 
“cobiça da riqueza e negligência do resto" (PLATÃO, 2012, p. 393). De fato, este é o sepultamento da noção cívica grega de participação ativa no cotidiano político da polis.

A transição da oligarquia para a democracia ocorre quando os pobres obtêm vitória sobre os ricos e tomam o governo do Estado. Amparado por tais convicções, Platão não poderia deixar de ter uma visão pessimista quanto ao governo democrático. Seu olhar negativo para com a democracia, forma de governo tão celebrada em nossos tempos, é compreensível quando se estabelece um olhar global no pensamento platônico: a polis perfeita se apoia sobre a divisão de classes promovidas e controladas pelo aparato educacional do Estado. Sua visão de justiça e liberdade é adstrita a este locus a qual pertence cada cidadão. Por outro lado, o indivíduo é livre quando não se sujeita aos grilhões de suas próprias paixões. Contudo, para Platão, a liberdade na democracia impera de tal modo que não se constrói nada de substancial para a sociedade. Ou seja, a concepção ampla liberdade dialoga de modo muito próximo à anarquia, contexto em que não há justiça.

Com efeito, na regra já esboçada anteriormente, homens despreparados não formariam a polis adequada. A proximidade que Platão estabelece entre liberdade e anarquia é sem precedentes em virtude de sua leitura da Atenas que condenara o seu mestre Sócrates à morte. Assim, este é o quadro humano na passagem da oligarquia para a democracia, na qual os sujeitos não possuem aptidão para as artes mais elevadas - filosofia, física, música, ginástica - o que culminaria em uma organização política semelhante ${ }^{12}$. Os valores propagados pela democracia são a insolência como boa educação, a anarquia como liberdade, a prodigalidade como generosidade e a desfaçatez como coragem (PLATÃO, 2012, p. 390). Logo, cidadãos com virtudes pouco cultivadas não são cidadãos virtuoso e não formarão uma esfera política que os conduza para a liberdade e para a justiça. Este é o quadro da democracia em sua visão.

Neste panorama, como não há regras fundadas nas leis, na autoridade ou na tradição, mas se impera a liquidez indelével da excessiva liberdade individual sem lastro na sabedoria ou na virtude, tem-se como resultado a aproximação da democracia com a tirania, proporcionada pela tolerância em demasia e falta de limites. Para Platão, cuja apoteose sempre se direciona para o equilibro e a contenção, a causa de vários males é explicada pela ausência de limites. A democracia é o píncaro da liberdade anárquica e a tirania é a sua

\footnotetext{
${ }^{12} \mathrm{Na}$ visão pedagógico-política de Platão, "nunca uma pessoa poderia se tornar um homem de bem, se logo, desde a infância, não brincasse no meio de coisas belas e não se dedicasse a todas as atividades dessa qualidade" (PLATÃO, 2012, p. 385).
} 
anulação $^{13}$. Platão enuncia a fórmula de que o excesso costuma ser correspondido por uma mudança radical em seu sentido oposto. Em outras palavras, a total liberdade gera a servidão plasmada na tirania draconiana, o máximo e o mínimo sendo apresentados como faces opostas de uma mesma moeda. O processo de transição entre liberdade e sua privação tirânica ocorreria pela divisão da sociedade democrática em políticos, ricos e pobres (as duas últimas classes são legado da oligarquia).

Valendo-se de uma espécie de populismo, o tirano formaria o corpo de seus seguidores - por meio do perdão de dívidas e distribuição de terras de grupos opositores vencidos - e eliminaria seus adversários com apoio irrestrito de setores volumosos da sociedade. Ou seja, o engodo o alçaria ao governo. A liberdade seria progressivamente subtraída dos cidadãos para a manutenção do estrito controle do poder e do governo. Deste modo, é tênue a separação entre democracia e tirania e dramático o seu resultado. O caminho mais seguro, sob o olhar de Platão, seria a aristocracia do pensamento, em que todos participam ativamente da construção da polis a partir de sua classe social.

\section{A filosofia política de Aristóteles}

Aristóteles nasceu em 384 a.C. em Estagira, na Macedônia. Era um meteco, ou seja, um estrangeiro estabelecido em Atenas, e como tal não possuía a cidadania ateniense, de modo a não dispor de direitos políticos. Estudou na Academia fundada por Platão até a morte de seu mestre, em 347 a.C. Por não ser cidadão ateniense, não pode herdar a Academia, tendo esta sido passada a Espeusipo, sobrinho de Platão. Com isto, Aristóteles foi lecionar em Assos e depois assumiu o encargo de educar o jovem Alexandre Magno. Este é um momento esplendido da história: a junção de um dos maiores pensadores de todos os tempos com o

\footnotetext{
${ }^{13}$ Segundo Platão, "a liberdade em excesso, portanto, não conduz a mais nada que não seja a escravatura em excesso, quer para o indivíduo, quer para o Estado" (PLATÃO, 2012, p. 396). Jaeger (1995, p. 947-949) comenta que a liberdade democrática para Platão consiste sobretudo em se sentir livre de todo tipo de deveres, e não em se submeter por si próprio a certas normas interiores. Cada um organiza a sua vida como melhor lhe apraz [...]. A democracia surge aos olhos de Platão como um Estado em que pululam os homens de todos os tipos, como um armazém de todos os tipos de constituições, onde cada um toma o que está mais de acordo com os seus gostos particulares. Quem não quiser participar no Estado em nada, pode seguir este caminho, exatamente como poderia seguir o outro. Quem não quiser intervir na guerra, pode continuar a viver em paz, enquanto outros guerreiam. Aquele que se vir destituído do seu cargo pela lei ou por uma decisão judicial, continua apesar disso a governar, sem que ninguém lhe impeça. $\mathrm{O}$ espírito de tolerância impera aqui sobre a justiça.
} 
jovem que se viria a se tornar o maior conquistador do mundo antigo! Após Alexandre conquistar Atenas, Aristóteles retorna à sua antiga cidade para fundar o Liceu.

Apoiando-se sobre os ombros de Platão, Aristóteles o supera em grau e proporção para se tornar um digno titã do conhecimento, grande polímata do mundo antigo. É considerado por muitos como o maior dos pensadores da Antiguidade. A gama de temas discutidos e a magnitude de seu trabalho o fez alcançar um "conhecimento enciclopédico", abrangendo lógica, metafísica, ética, política, história natural, psicologia, fisiologia, poesia, retórica, química, astronomia, mecânica e matemática (BÖCKENFÖRDE, 2012, p. 131).

O pensamento de Aristóteles guarda algumas semelhanças superficiais ao de Platão, sobretudo no que tange a propósitos fundamentais, mas em geral são modos de pensar opostos. Aristóteles também cultivava a polis como o locus para a plenitude da vida humana. A eudaimonia aristotélica se bifurca na vida íntegra na cidade bem como agir em conformidade com o conhecimento obtido por meio da filosofia. Todavia, ao contrário de Platão, possuía profunda inclinação pela indução, observação e experimentação, métodos científicos de trabalho que perpassam quase todas as temáticas que foram seu objeto de estudo $^{14}$. Na seara política, não seria diferente. Aristóteles não visa conceber uma polis idílica nos moldes da Callipolis descrita na politeia platônica, mas perfaz uma análise que envolve a realidade político-institucional de diversos povos de sua época, retirando daí suas conclusões após fecundo processo de comparação e deliberação.

\section{1 Liberdade e interioridade: contingência e incontigência}

A categoria da livre vontade, consoante exposto anteriormente, era desconhecida para os gregos. Aliava-se a noção de necessidade. A liberdade adquiria duas conotações, a saber: uma política, cujo escopo era demonstrar se o sujeito era livre ou escravo, e uma segunda categoria que dizia respeito ao estado físico factual, isto é, relacionava-se com o indivíduo e sua capacidade física em abstrair conhecimento. A liberdade, portanto, era um fato cotidiano e não necessariamente uma questão a ser levantada pelos filósofos, como a justiça ou a virtude.

\footnotetext{
${ }^{14}$ Böckenförde (2012, p. 133) disseca o método de Aristóteles em uma tríade: após verificar a ocorrência de um fato digno de aprofundamento, é preciso primeiro levantar os fenômenos, o que significa reunir e examinar todas as opiniões correntes para em seguida, segundo ponto, trabalhar as dificuldades, resolvendo as contradições e deixando de lado os pontos que não passíveis de uma estrutura interna de coerência lógica. Por fim, esclarecer o conteúdo e a verdade das concepções mais importantes que se aproximam da verdade.
} 
Entretanto, no livro Metafísica, Aristóteles trabalha esta segunda categoria de liberdade na ideia de que tudo pode ser ou não ser (princípio da não contradição), tudo acontece ou não acontece. Mas aquilo que acontece e poderia não ter acontecido atingiu este estado por acidente ou por contingência. Ou seja, a contingência ou o acidente criam uma terceira via para algo que deveria ter acontecido ou não. Trata-se do limiar da noção volitiva, isto é, por qual razão se agiu de um modo e não de outro? Na fronteira entre o querer e o não querer, poucas coisas são tão contingentes como a vontade humana, que é livre, sob pena de se atirar os seres humanos em processos determinísticos. Segundo David Ross, a indagação do pensador grego acerca da contingência repousa em sua investigação sobre o desejo e o intelecto: o homem contingente é o que conhece a volúpia de suas paixões e resiste aos seus apelos, contenda que o incontingente não trava, mas se entrega mesmo tendo ciência de que não deveria fazê-lo (ROSS, 1987, p. 227).

Com efeito, "o homem incontingente, sabendo que o que faz é mau, o faz levado pela paixão, enquanto o homem contingente, conhecendo como maus os seus apetites, recusa-se a segui-los em virtude do princípio racional”. (ARISTÓTELES, 1984, p. 157-158). Aristóteles lembra que Sócrates, seguindo a linha de pensamento grega, não acreditava na existência da incontingência, do quero e não posso. Em suma, não seria concebível a um homem racional, de retidão, trilhar o caminho dos desejos, pois isto seria apenas possível aos ignorantes que efetivamente escolheriam tal caminho. Para Aristóteles, aquele que possui o conhecimento que não deveria agir em um sentido, que sabe que sua atitude não é razoável, e ainda assim o faz, age deste modo por possuir apenas um "conhecimento perceptual” e não um “conhecimento propriamente dito" (ARISTÓTELES, 1984, p. 161). Em outras palavras, não agiria por vontade, mas por não dispor do conhecimento necessário de que não deveria agir. David Ross conclui que o que falta à teoria aristotélica é o reconhecimento do fato de a incontingência se dever a uma fraqueza da vontade e não a uma falha de conhecimento (ROSS, 1987, p. 229) $)^{15}$.

\footnotetext{
15 Tércio Sampaio Ferraz Junior lembra, contudo, que a noção de liberdade do indivíduo, na esfera da interioridade, não era uma categoria grega. A liberdade estava na polis. Segundo o autor, "o sentido desta (liberdade) continua localizado na possibilidade de o homem conduzir-se por suas virtudes ao bem que lhe é próprio. Não há, ainda, a hipótese de o homem, por ser livre, ser imputável e responsável. A liberdade tem a ver, ainda, com a conduta humana na polis e não com a voluntariedade ou involuntariedade dos atos. Para que esta última hipótese ocorresse, seria necessária uma decidida subjetivação do tema, isto é, a proposição da liberdade como uma questão do sujeito em sua própria interioridade. A filosofia grega não chegou a essa formulação (JUNIOR, 2002, p. 82).
} 
Mas a vontade, conforme dito, não era uma categoria conhecida até então. A explicação para que a vontade não tenha obtido relevo na filosofia clássica, segundo Hannah Arendt (1995, p. 199), deve-se à maneira como os gregos compreendiam e mediam o tempo. O tempo era cíclico, isto é, não existia categoria de início e fim ou de passado e futuro, mas apenas o constante movimento dos corpos celestes e a natureza cíclica da vida. $\mathrm{O}$ todo celestial é eterno; os seres morrem após um longo ir e vir. É apenas na tradição judaico-cristão que se estabelece a noção de tempo linear, de um movimento retilíneo que ruma para o futuro e cujos acontecimentos são inéditos, apesar de guardar alguns reflexos do passado. Assim, Arendt deduz que a vontade ou o querer, sendo órgão espiritual cujo vetor aponta para o futuro, não representaria um problema a ser enfrentado na Grécia clássica.

\subsection{Zoon politikon e a necessária convivência humana}

No que tange ao âmbito político, locus para a compreensão da liberdade no período do helenismo clássico, torna-se necessário seguir o itinerário aristotélico para se apreender a diferença entre liberação e liberdade, enunciando a formação das comunidades humanas e analisando a polis e suas formas de governo. Aristóteles nasceu em um momento mais estável da democracia ateniense se comparado aos idos em que Platão escreve A República, sobretudo pela limitação do catálogo de competências conferida à Assembleia popular. Ao contrário de seu mestre, não nutriu profunda aversão a esta forma de governo.

Na obra Política, o Estagirita não tem como fundamental analisar as minúcias das formas governos que considerava adequadas e suas recíprocas, mas busca a essência por detrás do questionamento sobre o governo ideal. A filosofia política de Aristóteles também parte da ideia do Estado ideal. A noção fundamental que subjaz a obra Política se relaciona ao problema da formação do Estado/cidade. Em seu afã teleológico, a primeira indagação se relaciona com a natureza do Estado. Natureza, neste caso, não significa origem, mas finalidade, destinação.

É conhecida a doutrina aristotélica na qual as cidades surgem a partir de famílias. Este é o seu pressuposto fundamental. A formação comunitária mais básica decorrente da união de famílias é a aldeia, com um governo monárquico. Quando várias aldeias se unem, configurase a cidade ou Estado. De início a cidade se constituiu para a garantia das necessidades vitais dos indivíduos. Para Aristóteles, a finalidade da polis é garantir a vida boa (eudaimonia), a 
vida feliz possibilitada apenas pela convivência coletiva. O que diferencia os homens de animais como abelhas e formigas, que também têm a capacidade de se associarem, é o dom da palavra, da fala (ARISTÓTELES, 2000, p. 146).

As razões que justificam os homens terem se associado são o instinto de reprodução e a busca por autopreservação concebida na relação senhor e escravo (que não detém nada para sua segurança). Neste sentido, as duas formações básicas são: i) a casa, composta de homem, mulher e escravos, cujo objetivo é a satisfação das necessidades e carências cotidianas; ii) e a aldeia, a associação de várias famílias. A aldeia ainda é uma formação política deficiente pois seu escopo é a satisfação de instintos animalescos. O objetivo da polis, resultado da união de várias aldeias, ultrapassa a satisfação das necessidades e visa à boa vida ${ }^{16}$.

Aristóteles diferencia a natureza das coisas gerais, como a de um instrumento musical cujo propósito é criar algum tipo de som, e a dos seres vivos, cuja finalidade é imanente à própria vida. Assim, o fim da planta é crescer para se tornar forte, o fim dos animais são as sensações e apetites - por possuírem sistema nervoso central - e o fim do homem e das comunidades humanas é utilizar a razão e agir moralmente na presença de outros, no convívio do ambiente da polis. Portanto, a natureza humana é afeita a vida comunitária como uma inclinação natural. Esta é a emblemática tese aristotélica do zoon politikon, o homem é um animal político, isto é, sua dignidade se completa quando está na presença de outros. Todo aquele que for incapaz de viver na presença de outros "será uma besta ou um Deus" (ARISTÓTELES, 2000, p. 145-147 e 222).

Böckenförde (2012, p. 131 e 154) esclarece que a noção de polis, palco para a existência da justiça e liberdade, é diametralmente oposta se comparados os pensamentos de Platão e Aristóteles: o primeiro tem a cidade como condição primeira para a vida comum que evoluirá a partir do controle da estrita divisão do trabalho e formação de classes, enquanto Aristóteles vê na polis um constante processo de evolução, da família até o Estado, nela se ultimando as faculdades e capacidades humanas rumo ao bem viver que só é possível na convivência com os demais. Tal noção constitutiva do espaço público permite ao autor inferir que o essencial para a cidade de Platão é a unidade, à medida que Aristóteles concebe a

\footnotetext{
${ }^{16}$ Amartya Sen comenta que este ideal da vida boa pode ser um bom indicativo do gérmen fundamental da economia. Segundo ele: "a origem da economia foi significativamente motivada pela necessidade de estudar a avaliação das oportunidades que as pessoas têm para levar uma vida boa e as influências causais sobre essas oportunidades. Além do emprego clássico dessa ideia de Aristóteles, noções semelhantes foram muito usadas nos primeiros textos sobre contas nacionais e prosperidade econômica, cujo pioneiro foi William Petty no século XVII". (SEN, 2000, p. 40)
} 
pluralidade, pessoas distintas oriundas de famílias distintas convivendo para atingir a melhor vida possível, que é o telos (finalidade) da polis $^{17}$. Deste modo, Os homens convivem porque querem viver, mas fundaram a polis e realizam a política porque querem viver bem. É no ambiente civil que se completa a vida comunitária, porque somente nela as faculdades e capacidades próprias das pessoas (como língua, inteligência racional, percepção do bem e do mal, do justo e do injusto) alcançam completo desenvolvimento no sentido de uma vida boa e auto-suficiente. A liberdade conquistada no ambiente da polis é, portanto, parte da dignidade humana.

\subsection{A casa como apanágio da liberdade política e as formas de governo}

A arquitetura desta cidade aristotélica se divide entre homens livres e não-livres. A partir desta assertiva, abrem-se aqui dois mundos diametralmente distintos: o da casa e o da polis. Aristóteles reconhece que o poder existente na dicotomia destes dois locus da vida, o ambiente doméstico da casa e o espaço público da polis, são distintos pela natureza dos indivíduos envolvidos, servos e homens livres: o poder familiar é monárquico, centrado na figura do chefe de família, enquanto a relação no espaço público se dá entre homens livres e iguais. Em suas palavras: "o governo doméstico é uma espécie de monarquia: toda casa se governa por uma só pessoa; o governo civil, pelo contrário, pertence a todos os que são livres e iguais" (ARISTÓTELES, 2000, p. 17 e 153).

A superação da vida privada era necessária para a obtenção do status de cidadania. Em outras palavras, o elemento fundamental para a existência da liberdade era a inviolabilidade da casa grega, pois, sem ela, os chefes de família não obteriam a liberação de sua jornada laboral diária para a vida na polis. Nas palavras de Aristóteles, "é consenso que num Estado bem-organizado os cidadão devem liberar-se de todas as tarefas inferiores" (ARISTÓTELES, 2000, p. 194). Will Durant (2000, p. 96-97) reconhece o profundo desprezo que os gregos nutriam dos trabalhos manuais, repetitivos, que hipoteticamente destruiriam a inteligência e

\footnotetext{
${ }^{17}$ Aristóteles se mostra crítico em demasia à proposta da Callipolis de Platão, fundada na severa estrutura hierárquica unitária baseada nas classes estamentais. Segundo o Estagirita, "o Estado que se tornar progressivamente uma unidade deixará de ser Estado. A pluralidade, neste caso, é natural; e quanto mais o Estado se afastar da pluralidade, em direção à unidade, menos Estado será e mais próximo estará de uma família”, cujo regime de governo é despótico, como será tratado a seguir (ARISTÓTELES, 2000, p. 170). Neste compasso, nas palavras de François Châtelet et al, "o erro de Platão é querer reduzir seres diferentes à igualdade aritmética e aplicar autoritariamente uma proporcionalidade geométrica à ordem social" (CHÂTELET; DUHAMEL; PISIER-KOUCHNER, 2009, p. 20).
} 
não permitiriam aos cidadãos dispor do tempo indispensável para se ocupar da política. Ao possuir o controle sobre o lar que lhe guarnecesse de bens, eles poderiam se desonerar do trabalho e ter o lazer para assumir, além da esfera privada de suas vidas, o bios politikos (ARENDT, 2010, p. 28). Somente desta maneira seriam verdadeiramente livres ${ }^{18}$.

O grupo de cidadãos livres eram os homens, senhores de uma casa com mulheres, idosos e escravos, que trabalhavam e possibilitavam a sua liberação para as atividades da polis. Contudo, a conquista da liberdade não era consectário da mera liberação. Nas reflexões da filósofa Hannah Arendt, os fatores que possibilitavam a liberdade eram a companhia de outros homens em igual condição - senhores liberados da necessidade de prover para a sua subsistência - e um espaço político para a qual pudessem se reunir. Neste contexto, comenta a autora, ser livre significava "ser isento da desigualdade presente no ato de governar e moverse em uma esfera na qual não existia governar nem ser governado" (ARENDT, 2010, p. 39).

Isto significa que no espaço político todos os cidadãos dispunham de igualdade (homoioi), não havendo relações fundadas em situações de mando e obediência. Desta forma, observa-se a existência de panoramas opostos: o da casa, locus em que predominava o despotismo por vezes draconiano do chefe de família, e a polis, espaço composto por iguais e destituído de modelos hierárquicos, com exceção apenas para os momentos de guerras em que um líder militar era essencial.

Dentre as duas concepções expostas, para Hannah Arendt, a verdadeira noção de liberdade era a política. Segundo esta pensadora, "o que todos os filósofos gregos tinham como certo, por mais que se opusessem à vida na polis, é que a liberdade situa-se exclusivamente na esfera política", isto é, livres eram os cidadãos que participavam da polis (ARENDT, 2010, p. 37). Já a força e a violência eram os traços marcantes da esfera privada, por serem os únicos meios de se vencer a necessidade imposta pelos fatores biológicos. Consoante se denota, a centelha política na Grécia clássica era oposta a noção moderna e contemporânea. Para os gregos, a possibilidade de participação nas discussões políticas compunha o quadro legitimador para a aquisição da liberdade, benesse incomensurável para aquela sociedade, um contexto oposto a partir da ascensão do Estado moderno liberal na qual

\footnotetext{
${ }^{18}$ Segundo Hannah Arendt, "a liberdade como fenômeno político nasceu com as cidades-Estado gregas. Desde Heródoto, ela foi entendida como uma forma de organização política em que os cidadãos viviam juntos na condição de não dominação, sem divisão entre dominantes e dominados. Essa noção de não domínio se expressava na palavra "isonomia", cuja principal característica entre as formas de governo, tais como foram enumeradas pelos antigos, consistia na ausência completa da noção de domínio. A polis seria uma isonomia, não uma democracia" (ARENDT, 2011, p. 58).
} 
a atividade política se torna um percalço para a busca dos interesses financeiros pessoais, sendo necessário profissionalizar tal atividade, isto é, atribuir a um terceiro representante ${ }^{19}$.

O critério de cidadania para Aristóteles deveria ser distinto do que se tem na modernidade, baseada em fatores territoriais ou sanguíneos. Cidadãos seriam apenas os nascidos de pais nesta condição - um escravo jamais geraria um filho com cidadania ${ }^{20}$, e somente eles opinariam nas questões atinentes ao Estado. Em suas palavras, "o melhor Estado não fará do trabalhador um cidadão". Para o autor, nem todos deveriam opinar nas questões atinentes ao Estado - "o melhor Estado não fará do trabalhador um cidadão" (ARISTÓTELES, 2000, p. 220). Esta é questão de relevo para a análise aristotélica uma vez que a composição do corpo dos cidadãos é elemento fundamental para a caracterização da forma de um Estado - a democracia é o regime em que a maioria é soberana; no caso da oligarquia, haveria apenas uma minoria em tal condição, ou ainda a monarquia que legitima apenas um para o exercício da política.

Além do critério da cidadania, a finalidade do Estado é o segundo fator preponderante, pois determina o exercício do governo. O olhar teleológico de Aristóteles sobre a polis e suas formas de governo indaga se o objetivo de sua formação é o bem comum ou o bem próprio. Assim, o Estagirita estabelece que a aristocracia, a monarquia e a politia são formas que visam a coletividade dos cidadãos, enquanto a oligarquia, a democracia e a tirania tendem a buscar objetivos próprios, sendo, portanto, formas degeneradas de constituição - a oligarquia favorece os ricos, a democracia os pobres e a tirania somente o próprio tirano.

A questão que subjaz o esquema aristotélico é a de governos que visam o bem-estar comum. O autor não se limita a considerar uma forma ideal, tanto que afirma: "sempre que ou o Um, ou a Minoria, ou Todos governam, tendo em vista o bem-estar comum, essas constituições são justas; mas se procuram apenas o beneficio de uma das partes, seja ela o Um, a Minoria ou Todos, estabelece-se um desvio" (ARISTÓTELES, 2000, p. 223-224). Não

\footnotetext{
${ }^{19}$ Esta diferença fica muito clara no clássico texto de Benjamin Constant, Da liberdade dos antigos e dos modernos.

${ }^{20}$ Esta diferença é expressa por David Ross nos seguintes termos: "a concepção aristotélica de cidadão difere grandemente da concepção moderna, pois tem em vista, não um governo representativo, mas sim um governo direto. O seu cidadão não tem somente a sua palavra a dizer a respeito da escolha dos seus legisladores. De fato, cada cidadão deve realmente governar na sua vez, e não meramente no sentido de ser um membro do executivo, mas no sentido, bem mais importante para Aristóteles, de ajudar na elaboração das leis do seu estado, isto porque ao executivo apenas compete a função, comparativamente mais pequena, de completar as leis quando estão são inadequadas devido a sua generalidade. É com base nesta concepção elevada dos deveres do cidadão que Aristóteles restringe estritamente o corpo dos cidadãos. O camponês ou o lavrador, que podem ser pensados como capazes de escolher os seus representantes, são naturalmente julgados incapazes de governar realmente" (ROSS, 1987, p. 253)
} 
há forma ideal de governo. Aristóteles não olvida que todas elas possuem parcelas positivas e negativas e que em dado momento podem se desviar do rumo delineado. Em razão disto, a melhor é aquela que possa ser implementada, senão por todos, pela grande maioria dos cidadãos, de modo a favorecer ao bem comum de todos e permitir que a polis atinja seu objetivo. E isto somente será possível pela forma mista, o meio termo entre a aristocracia e a democracia.

O panorama político ideal seria a centralização no homem mais virtuoso, isto é, aquele que viva para a polis e propicie o melhor para todos os cidadãos. Contudo, Aristóteles considera a monarquia inadequada por não conseguir unir força e virtude. A aristocracia é a melhor forma de governo, mas seu desarranjo ocorre pela facilidade com que vende cargos políticos por não possuir base econômica permanente. Por outro lado, a democracia é inferior a aristocracia por se pautar em uma noção falsa de igualdade plena. A virtude democrática está na decisão tomada por grande número de pessoas, uma vez que a decisão coletiva majoritária é melhor que a minoria virtuosa. Desta forma, o governo constitucional, longe de ser o ideal, é aquele capaz de oferecer o melhor modo de vida aos cidadãos, garantindo o respeito a lei que salvaguarda a liberdade política.

\section{CONSIDERAÇÕES FINAIS}

O pensamento de Platão e Aristóteles marca um período em que a política era o centro da vida comunitária. Embora a democracia grega estivesse em declínio, estes autores desenvolveram sua linha de raciocínio tendo a polis como referência. Assim, ao libertar o seu filósofo dos grilhões da caverna, Platão indica que o governo mais adequado será aquele exercido pelos mais sábios, que deverão retornar à escuridão da irracionalidade para doutrinar os seus demais e comandar a política. Nesta arquitetura fundamental que ele funda a Callipolis, a cidade idílica que proporcionará a verdadeira justiça e tornará os cidadãos livres. O regime de governo mais adequado aos seus desideratos é o aristocrático, baseado no conhecimento: Platão desenvolve uma cidade dividida por classes, em que todos têm direito à mesma educação e a divisão social ocorre pelo tempo em que cada indivíduo se dedica aos estudos. A liberdade encontrará respaldo neste sistema, uma vez que livre é aquele que desempenha suas atividades na exata dimensão de suas capacidades, e a justiça estará presente quando cada um agir no seu domínio preestabelecido. Surge com esse pensador a noção da 
política sob o signo da técnica: o povo estaria deslegitimado para o governo, devendo ficar a cargo dos mais sábios ou dos melhores. Por esta razão, naturalmente ele verá a democracia como uma forma degenerada de governo.

Aristóteles, por sua vez, é o grande pensador da Antiguidade. Polímata, desenvolveu uma vasta obra que infelizmente se perdeu no decorrer da história. Sua concepção política se volta para a eudaimonia, isto é, o objetivo da polis é a vida boa para os seus cidadãos. A estrutura social é constituída por duas esferas: a privada e a pública. A casa era o locus da família, em que o seu chefe exercia um governo de dominação. Liberando-se do trabalho, ele poderia adentrar a esfera da polis, na qual era livre para se manifestar e auxiliar na condução das questões de Estado. A cidadania era um elemento ínsito àqueles que dispunham de uma estrutura familiar que o guarnecesse. Por isto, mulheres e escravos estavam completamente excluídos dessa condição. Dentre todas as formas de governo, o Estagirita acreditava o melhor seria a mescla da aristocracia e da democracia por unir elementos importantes para a manutenção da cidade e a tomada de decisões coletivas estratégicas. 


\section{REFERÊNCIAS}

ARENDT, Hannah. A Condição Humana. 11 ed. Rio de Janeiro: Forense Universitária, 2010.

, Hannah. A Dignidade da Política. Rio de Janeiro: Relume Dumará, 1993.

, Hannah. A Vida do Espírito. Rio de Janeiro: Relume Dumará, 1995.

, Hannah. Entre o Passado e o Futuro. 7 ed. São Paulo: Perspectiva, 2011.

ARISTÓTELES. Política. São Paulo: Nova Cultural, 2000 (Os Pensadores).

Ética a Nicômaco. 3 ed. São Paulo: Abril, 1984 (Os Pensadores).

BÖCKENFÖRDE, Ernst-Wolfgang. História da Filosofia do Direito e do Estado: Antiguidade e Idade Média. Porto Alegre: Sérgio Antonio Fabris, 2012.

CHÂTELET, François; DUHAMEL, Olivier; PISIER-KOUCHNER, Evelyne. História das Idéias políticas. 2 ed. Rio de Janeiro: Jorge Zahar, 2009.

DURANT, Will. A História da Filosofia. São Paulo: Nova Cultural, 2000.

JAEGER, Werner. Paidéia: a formação do homem grego. São Paulo: Martins Fontes, 1995.

JUNIOR, Tércio Sampaio Ferraz. Estudos de Filosofia do Direito: reflexões sobre o Poder, a Liberdade, a Justiça e o Direito. São Paulo: Atlas, 2002

PLATÃO. A República. 13 ed. Lisboa: Calouste Gulbenkian, 2012.

ROSS, David. Aristóteles. Lisboa: Dom Quixote, 1987.

SEN, Amartya. Desenvolvimento como Liberdade. São Paulo: Companhia das Letras, 2000. 